\title{
Inherited dental anomalies in the horse (Equidae, Equus caballus)
}

\author{
Natalia N. Spasskaya
}

\begin{abstract}
Under consideration are different kinds of congenital dental anomalies in the domestic horses. It is shown that such anomalies are more frequent in the native breeds horses as compared to the cultivated breeds. Some anomalies, in particular false polidontiya of P1, are detected more often in younger animals, which is explained by possible loss of extra tooth during the animal's life. Frequency of occurrence of dental anomalies is shown to increase in isolated groups, for example, in Iceland and in island of feral horses, as a result of inbreeding.
\end{abstract}

KEY WORDS: dental anomalies, domestic horses, horse breeds, inbreeding.

Natalia N. Spasskaya [equusnns@mail.ru], Zoological Museum of the Lomonosov Moscow State University, Bol'shaya Nikitskaya st., 6, Moscow, 125009, Russia

\section{Врождённые зубные аномалии у лошадей (Equidae, Equus caballus)}

\begin{abstract}
Н.H. Спасская
РЕЗЮМЕ. Исследованы врожденные зубные аномалии у домашних лошадей, приводится описание разных видов. Впервые проведен анализ частоты проявления аномалий у разных пород: показано, что у аборигенных пород этот показатель выше, чем у культурных пород. Некоторые аномалии, в частности ложная полидонтия по Р1, значительно чаще регистрируется у молодых животных, что связано с возможной потерей зуба в течение жизни животного. В изолированных группировках, например, у исландских и островных одичавших лошадей, в результате действия инбридинга частота встречаемости зубных аномалий возрастает.
\end{abstract}

КЛЮЧЕВЫЕ СЛОВА: зубные аномалии, домашние лошади, породы лошадей, инбридинг.

\section{Introduction}

There is a lot of researches upon dental anomalies in mammals. They have been studying extensively aimed at both biological (variability, inheritance, evolutionary significance, etc.) and practical (medical and veterinary) purposes. The most of those researches were made based on some carnivore and primate species. Meanwhile, investigations of ungulate mammals are much less numerous, with perissodactyles being the least studied among them, if veterinary examinations are not counted.

Dental anomalies are defined by various researchers and medical experts as any deviations from the typical tooth morphology and development, not infrequently without discriminating between inherited and life-time acquired (Dixon \& Dacre, 2005; Easley, 2006; Peters et al., 2006). The latter may be caused by individual feeding and behavior features, deceases, traumatism, etc. However, the most interesting are just the inherited malformations, which are usually classified as following (i.e. Korneven \& Lesbr, 1932):

1. Anomalies in number:

1.1. oligodonty, that is reduction of the teeth number as compared to the norm. With this, the teeth occluding with the missing ones remain unworn and be- come noticeably larger than others in respective dental group;

1.2. polydonty, that is increase of the teeth number as compared to the norm. The true polydonty is resulted from splitting of a tooth belonging to either permanent or to milk dentition. The false polydonty is resulted from preservation of one or occasionally more milk teeth together with permanent ones after their eruption.

2. Orthodonty or misalignment - anomalies in position and/or orientation, that is alteration of tooth location within the dental arcade, which may involve:

2.1. displacement of the entire tooth relative to the dental arcade axis without its rotation;

2.3. rotation of the tooth around its vertical axis; the both variants may combine occasionally;

3. Anomalies in degrees of the teeth development, that is their hypo- or hypertrophy;

4. Anomalies in the shape of dental crown.

It is usually difficult to identify precisely causes of the latter two types of anomalies, as they might be due to both inherited and external (mechanical etc.) conditions. Therefore, in the present paper the main attention is paid to the former two types of dental anomalies.

Notwithstanding that particular dental anomalies were studied with much details in the domestic horse, a number of questions remains unclear concerning some 
Table 1. Studied osteological material on the native breeds of the domestic horse and feral horses (Vodny Island population).

\begin{tabular}{|c|c|c|c|c|c|c|c|}
\hline \multirow{2}{*}{ Samples } & \multirow{2}{*}{$\begin{array}{l}\text { Numbers of } \\
\text { skulls** }\end{array}$} & \multicolumn{6}{|c|}{ Age groups } \\
\hline & & $\begin{array}{c}<1 \\
\text { year }\end{array}$ & $\begin{array}{c}1-3 \\
\text { years }\end{array}$ & $\begin{array}{l}3,5-5 \\
\text { years }\end{array}$ & $\begin{array}{c}5,5-10 \\
\text { years**** }\end{array}$ & $\begin{array}{c}10,5-15 \\
\text { years*** }\end{array}$ & $\begin{array}{c}>15 \\
\text { years } * * *\end{array}$ \\
\hline \multicolumn{8}{|c|}{ Horses breeds } \\
\hline Kazakh & $61(30 / 24)$ & - & 6 & 1 & $17 / 10$ & $5 / 9$ & $8 / 5$ \\
\hline Yakut & $68(30 / 24)$ & 4 & 3 & 7 & $22 / 18$ & $2 / 5$ & $6 / 1$ \\
\hline Mongol & $21(16 / 5)$ & - & - & - & $9 / 5$ & $3 /-$ & $4 /-$ \\
\hline Bashkir & $10(1 / 4)$ & - & 3 & 2 & $1 / 2$ & - & -12 \\
\hline Yomud & $12(2 / 10)$ & - & - & - & $1 / 7$ & $-/ 1$ & $1 / 2$ \\
\hline Island & $78(23 / 26)$ & 2 & 17 & 10 & $17 / 21$ & - & $6 / 5$ \\
\hline Total: & $250(101 / 94)$ & 6 & 29 & 20 & $67 / 63$ & $10 / 15$ & $25 / 15$ \\
\hline \multicolumn{8}{|c|}{ Feral horses (Vodny Island samples) } \\
\hline 1991-1995* & $23(13 / 10)$ & - & - & - & $2 / 1$ & $6 / 3$ & $5 / 6$ \\
\hline 1996-2000 & $49(27 / 18)$ & - & - & 4 & $13 / 10$ & $14 / 8$ & - \\
\hline $2001-2005$ & $181(40 / 60)$ & 22 & 27 & 32 & $40 / 60$ & - & - \\
\hline $2006-2010$ & 220 & 128 & 60 & 32 & - & - & - \\
\hline Total: & $473(80 / 88)$ & 150 & 87 & 68 & $55 / 71$ & $20 / 11$ & $5 / 6$ \\
\hline
\end{tabular}

* years of birth; ** total skulls for breed (adult male/female); for mature specimens only; *** male/female.

regularities of their occurrence in the horse populations. Among these, dependence of the frequency of inherited dental anomalies on the horse breed belonging and on degree of isolation of the horse population seems to be most interesting.

The principal aim of the present paper is to provide empirical data allowing to consider the latter two and some other related questions.

\section{Material and methods}

For analysis of effect of the breed belonging on dental anomalies, two horse breed groups were studied. The first group included primitive aboriginal Kazakh, Mongol, Yakut, Yomud, Bashkir, and Island breeds; the second group included several modern European cultural breeds (see below for details).

The cranial materials studied are listed in the Table 1. Those on the aboriginal horse are kept in the different collections (see Appendix 1). For feral horses (Vodny Island, Russia) all osteological materials are remained on the island. Each skull is identified by its field number and geographical coordinates. These data are available from the author by individual requests.

Because of shortage of the original osteological materials on the European cultural breeds kept in the museums, the following published data were also analyzed: 955 specimens of various breeds (Peredelsky, 1927); 40 specimens of various breeds (Rudick, 1973); 440 specimens including 140 ponies, 117 thoroughbred, 94 thoroughbred's hybrids, 8 cart-horses and 41 other breeds (Dixon et al., 1999a,b); 50 specimens, of which 37 were horse (including 2 cart-horses) and 13 were ponies, miniature horse not included (Brigham \& Duncanson, 2000a); 100 specimens of various breeds (Brigham \& Duncanson, 2000b) ${ }^{1}$.

For analysis of the effect of population isolation on frequency of dental anomalies, two feral horse populations were studied in more details, namely the Island horse and the Vodny Island feral horse (the latter island being a part of Rostov Reserve located on the ManychGudilo Lake, Ciscaucasia, South Russia). In order to determine temporal dynamics of dental anomalies frequency, the Vodny Island feral horse sample was divided into several age groups according to the years of birth of respective animals, with taking into consideration their longevity.

For all the skulls studied, their sex and age were determined. Individual age was determined bases on particular tooth eruption and wear (Kuleshov \& Krasnikov, 1928; Korneven \& Lesbr 1932; Durst, 1936), with additional criterion provided by skull sutures fusing (Vokken et al., 1961; Svechin, 1976). Gender identity of adults ( 5 years and older) was determined based on canines presence/absence.

All raw data are processed by non-parametric statistic methods by means of Statistica 7 for Windows. Nonparametric methods were basically employed, with use of correction of statistic parameters for the small sample.

${ }^{1}$ A number of researchers have not specified breeds of horses. 


\section{Results and discussion}

Types and kinds of dental anomalies in the domestic horse

In this section, the main attention is paid to deviations in number, position, orientation as well as in development of the teeth ${ }^{1}$.

Oligodonty is fairly well studied in the domestic horse. It is more reliably discovered in the posthumous remains, as it is usually hard to distinguish between absent and underdeveloped teeth covered by soft tissues in the alive animals. It involves the following teeth:

1. Incisors

1.1. reduction of number of permanent incisors (Bateson, 1894; Peredelsky, 1927; Korneven \& Lesbr, 1932; Durst, 1936; Brigham \& Duncanson, 2000a). This anomaly is recorded in our materials (Fig. 1A);

1.2. incisors concrescence, with formation of a bigger one of quite typical shape (Bateson, 1894);

1.3. lack of one or two of incisors belonging to the permanent generation, sometimes with presence of milk ones in adult horses (Bateson, 1894; Korneven \& Lesbr, 1932);

2. Canines: absence of one or several canines, usually in the upper and less frequently in the lower jaws. This anomaly is recorded in our sample (Fig. 1B);

3. Checkteeth: lack of praemolars or molars (Korneven \& Lesbr, 1932; Dixon et al., 1999b). We recorded absence of several teeth of this kind in the dental arcade (e.g. see Fig. 1C).

True polydonty occurs more frequently in the incisive portion of the horse dental arcade and less so in its canine and checkteeth portions (Korneven \& Lesbr, 1932).

1. Occurrences of 8 to 24 incisors within the same arcade were recorded (Korneven \& Lesbr, 1932; Dixon et al., 1999a);

2. Duplicated canines situated within the dental arcade without any free space between them were recorded (Korneven \& Lesbr, 1932; Dixon et al., 1999a; Easley, 2006);

3 . Increase of number of the teeth of the P3-M3 portion of the dental arcade was recorded not a once, while no case of P2 duplication has been registered by now (Korneven \& Lesbr, 1932; Rudick, 1973; Dixon et al., 1999b; Easley, 2006).

False polydonty is known to occur:

1. in the incisors (Korneven \& Lesbr, 1932; Durst, 1936; Dixon \& Dacre, 2005);

2 . in the canines, which may occur (permanent or more frequently milk ones) in the adult mares (Peredelsky, 1927; Korneven \& Lesbr, 1932; Durst, 1936; Rudick, 1973). We also revealed such extranumeral teeth in our materials. There is an opinion that this kind of anomaly may be caused by hormones (Peredelsky, 1927; Rudick, 1973);

\footnotetext{
${ }^{1}$ Usually, in the literature there is no indication on the position anomalies - upper or lower jaw.
}
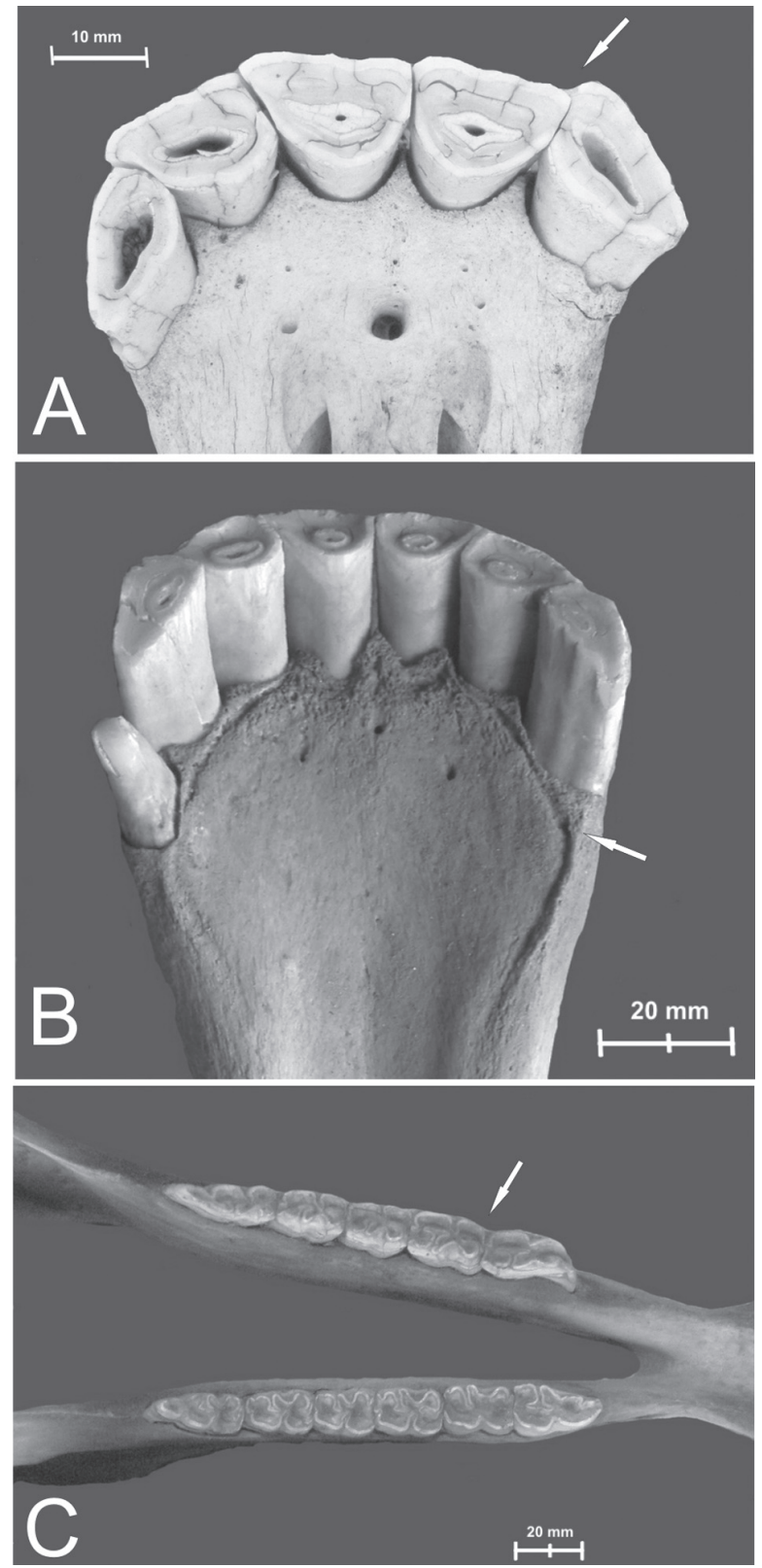

Figure 1. The dental anomalies types (occlusal view): A Oligodonty of the incisors in the upper jaw (female, 10 years old, feral horses Vodny Island, field ID 07-31); B - Oligodonty and orthodonty of the canines in the lower jaw (female, 8 years old, Danish breed, ID 1197 Museum of Natural History of Humboldt University, Berlin); C - Oligodonty of the cheek teeth in the lower jaw (male, 10 years old, Mongolian breed, ID 18059 Zoological Institute RAS, St. Petersburg).

3. In the checkteeth, most frequent is appearance of the so called "wolf tooth", which is actually the 1st premolar (Korneven \& Lesbr, 1932, Dixon et al., 1999a). Three degrees of its development can be recognized:

a) the tooth is weakly developed as but a thin "stick", it can fall out during lifespan with subsequent incomplete imperforation of its alveole (Fig. 2A); 

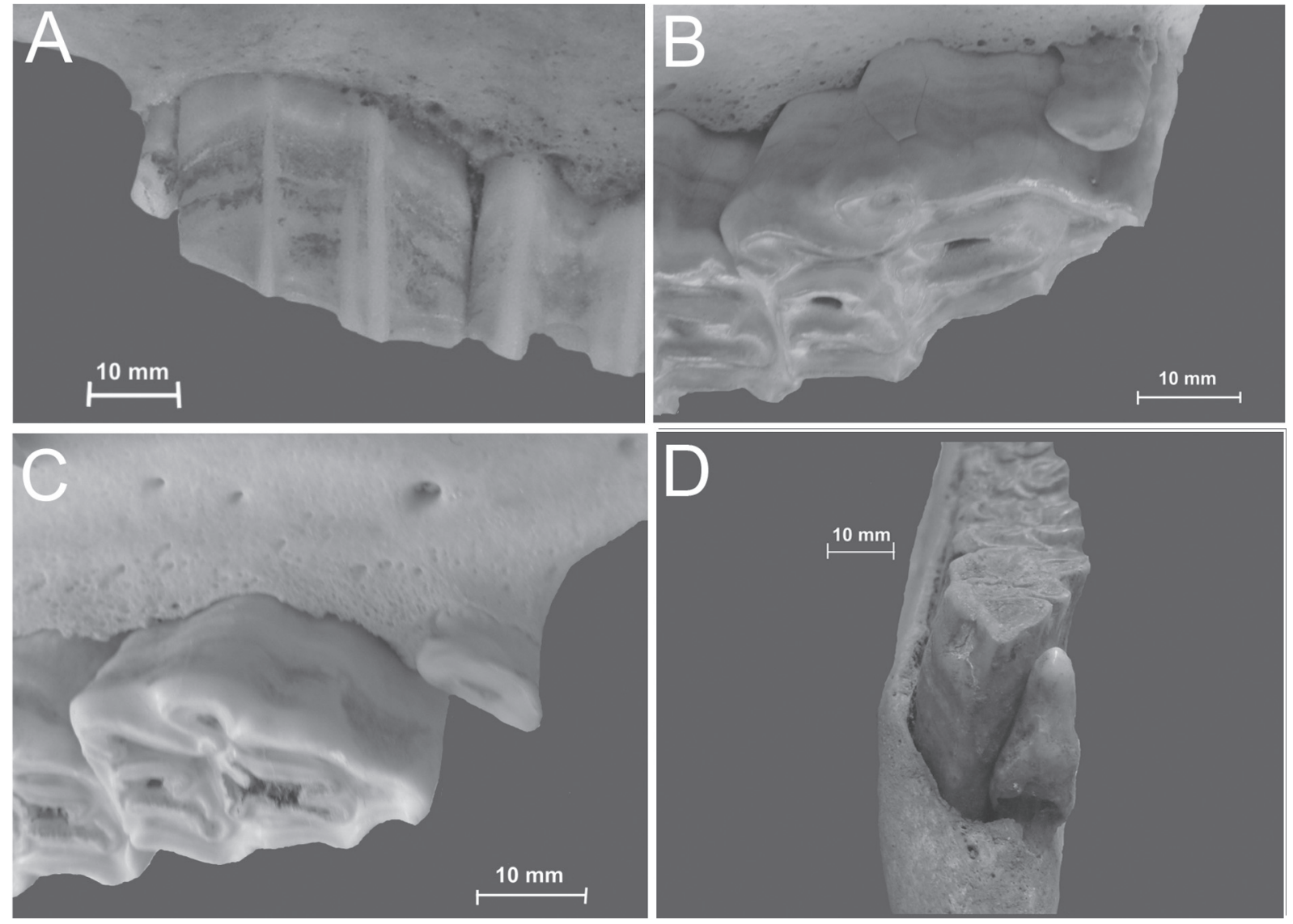

Figure 2. False polidonty of the premolars: A - P1 in the upper jaw (juvenile, 7 months old, feral horses Vodny Island, field ID 9M8-12) (buccal view); B - P1 in upper jaw (subadultus, 2,5 years old, feral horses Vodny Island, field ID 9M8-21) (lingual view); C - P1 in upper jaw (subadultus, 2,5 years old, feral horses Vodny Island, field ID 08N-29) (lingual view); $\mathrm{D}-\mathrm{p} 1$ in the lower jaw, front view (female, 8 years old, Borodino field ID 33) (frontal view).

b) the tooth is moderately developed, with its crown being not completely erupted and not reaching the level of the neighbor P2 (Fig. 2B);

c) the tooth is well developed, with its crown being completely erupted and having worn crown indicating its participation in chewing, but its size remains somewhat less than P2 (Fig. 2C).

The "wolf tooth" of the 1 st and $2 \mathrm{~d}$ degrees is much more frequently present in the upper jaw than in the lower one. We recorded the only case of the $3 \mathrm{~d}$ degree of "wolf tooth" development in the lower jaw of the excavated horse skull (Fig. 2D, the excavated horse skull; sanitary burial place at the famous Borodino village, Moscow District, 1812; see Spasskaya \& Janishevsky, 2013).

Orthodonty (misalignment) is recorded in:

1. incisors, which may appear as either their turn around their vertical axes (Korneven \& Lesbr, 1932) or their displacement from the dental arcade (Fig. 3);

Figure 3. Orthodonty of the incisors in the lower jaw (female, 15 years old, feral horses Vodny Island, field ID 9M92-6) (occlusal view).

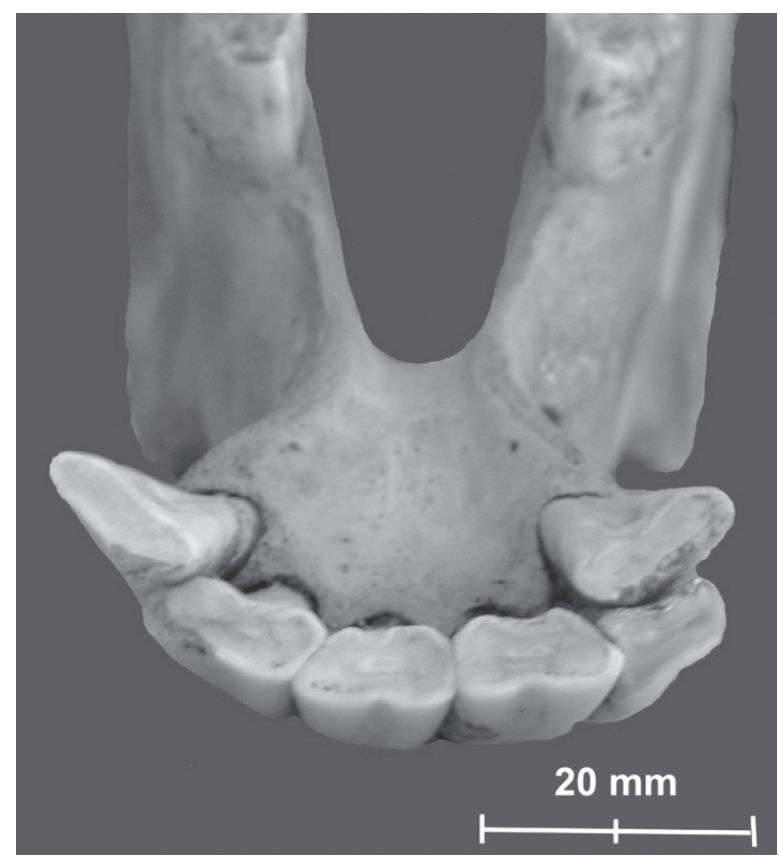



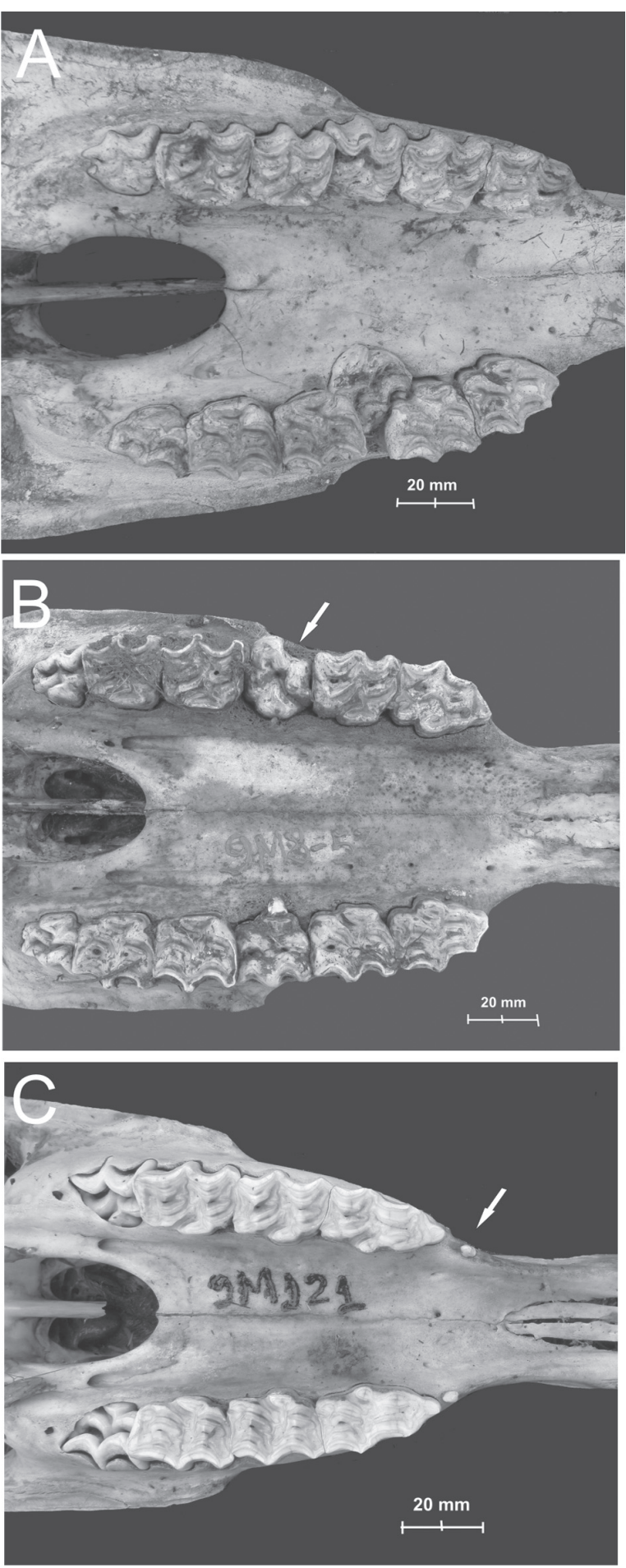

Figure 4. Orthodonty of the cheek teeth in the upper jaw (occlusal view): A - upper premolars lingual shifting (subadultus, 2,5 years old, feral horses Vodny Island, field ID 08A28); B - partial turn around vertical axe of upper premolars (subadultus, 3,5 years old, feral horses Vodny Island, field ID 9M8-53); C - displacement of P1 (juvenile, age than 1 year, feral horses Vodny Island, field ID 9M-121).

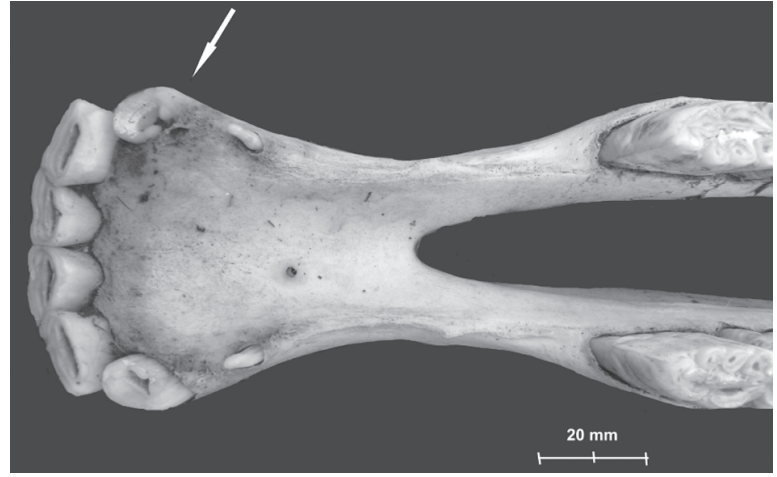

Figure 5. Unclosed cup on the incisor on the lower jaw (female, 7 years old, feral horses Vodny Island, field ID 9M25) (occlusal view).

2. canines, which may occur as their displacement either toward incisors with occasional replacement of some of them (Korneven \& Lesbr, 1932; Rudik, 1973; Brigham \& Duncanson, 2000) (Fig. 1B), or on the palate (Dixon et al., 1999a);

3. checkteeth (premolars and molars), namely their displacement from dental arcade lingually or buccally (Dixon et al., 1999b) (Fig. 4A); partial turn around their vertical axes (Dixon et al., 1999b) (Fig. 4B); displacement of P1 toward middle of diastema in the upper jaw (Fig. 4C).

Developmental anomalies most frequently involve teeth underdevelopment when dental crown does not erupt completely and remains covered by soft tissue. In such a case, this malformation looks externally like the tooth lacking in the alive horse. For respective dental group, these anomalies may be as follows:

1. in incisors, they are expressed as incomplete development of one or several teeth (Korneven \& Lesbr, 1932), or as unclosed "cup" in the 3rd incisors. The latter character is treated as atavistic, because it occurs usually in the zebras; it was revealed occasionally in the Przewalskii's horse (Gromova, 1949; Spasskaya, 2001); we recorded its rear occurrence in the domestic horse, as well (Fig. 5);

2. in canines, incomplete development occurs more frequently in upper than in lower jaws (Korneven \& Lesbr, 1932; Dixon et al., 1999a). We recorded this anomaly in the upper jaws in immature (more than 5 years old) stallions (Fig. 6);

3 . in checkteeth, several cases recorded in the sample studied herewith (Tab. 4).

\section{General characteristics}

It is to be noticed first of all that some tooth anomalies occur rarely in the horse, while others are more common.

Among rare ones are oligodonty and misalignment: for instance, frequency of canines oligodonty equals $0.8-6 \%$; frequency of misalignment equals $0.7-4 \%$ in incisors, $6 \%$ in canines, and $0.6-5.7 \%$ in checkteeth 


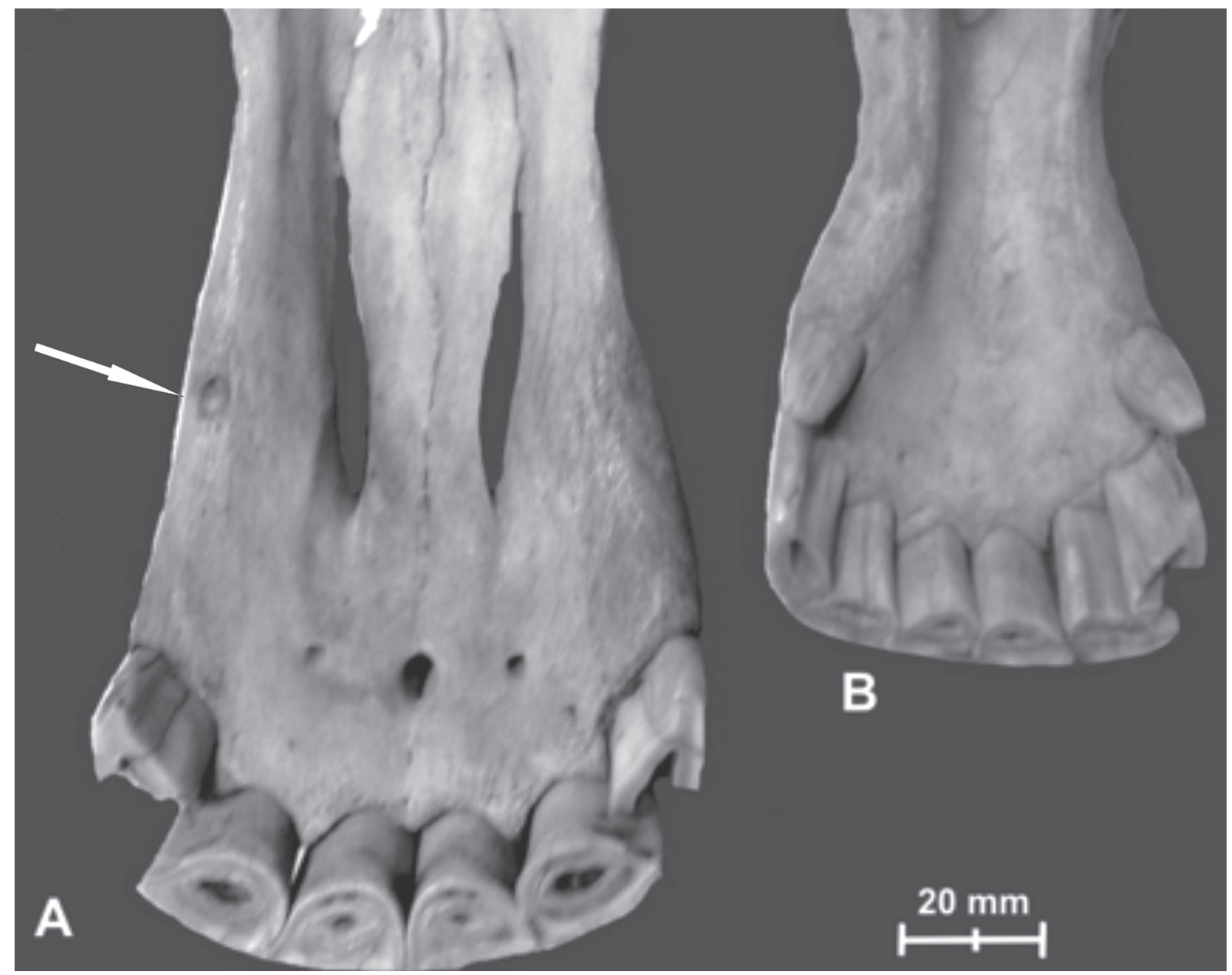

Figure 6. Developmental anomalies of the canines (occlusal view): A — the upper jaw (male, 6 years old, Iceland breed, ID 1348 Museum of Natural History of Humboldt University, Berlin); B - the lower jaw (ibid).

(Tab. 2). It is possible that quite low frequency of such dental malformations in the horse, as compared to other mammals (by various sources), is caused by very high integrity of the horse dentition, judging by high interdental correlations (Spasskaya \& Pavlinov, 2008).

The true polydonty occurs most often in the incisive portion of the dental arcade and is relatively rare in canines and checkteeth (Korneven \& Lesbr, 1932); it is about $2.5 \%$ in the latter according to our data (Tab. 3 ). The false polydonty occurs with frequency of $1.2 \%$ in the incisors, its frequency varies from $2-3$ to $5.7 \%$ in canines of adult mares, and it is 4 to $31.9 \%$ frequent in the 1st praemolar (Tab. 3).

There are noticeable differences in some dental anomaly frequencies between age groups at least in some horse breeds. This is especially true for the false polydonty of $\mathrm{P} 1$, with respective differences between young and adult animals being statistically significant: for the Vodny Island feral horses $\chi 2=25.7, p=0.000$, for the Icelandic breed $\chi 2=7.9, p=0.005$, for the Yakut breed $\chi 2=9.53, \mathrm{p}=0.002$.
Differences between aboriginal and cultural horse breeds

Researches of dental anomalies in the domestic horse usually conducted with the veterinary aims, so their dependence on specialization of different horse groups (i.e. sportive, draft, etc.) was in the spotlight. With this, the main attention was paid to acquired anomalies formed under the influence of the type of food supply and feeding mechanism, habits and way of life, diseases, injuries, etc. (Dixon \& Dacre, 2005; Easley, 2006). Contrary to this, specific features of their occurrence in different horse breeds were not traced.

Comparison of our data on the aboriginal horse breeds with those on the cultural breeds (published data) indicates the following. In the first group, the checkteeth oligodonty was recorded (1.6-4.8\%), which is not known to occur in the cultural breeds (Tab. 2). Among aboriginal horse, the false polydonty of canines 
Table 2. Records of inherited dental anomalies (oligodonty, orthodonty) in the domestic horses.

\begin{tabular}{|c|c|c|c|c|c|c|c|}
\hline \multirow[b]{3}{*}{ Breeds } & \multirow{3}{*}{$\begin{array}{c}\text { Total } \\
\text { number of } \\
\text { skulls }\end{array}$} & \multicolumn{6}{|c|}{ Types of inherited dental anomalies (in \%\% to total) } \\
\hline & & \multicolumn{3}{|c|}{ Oligodonty } & \multicolumn{3}{|c|}{ Orthodonty } \\
\hline & & Incisors & Canines & $\begin{array}{c}\text { Checkteet } \\
\text { (permanent } \\
\text { teeth) }\end{array}$ & Incisors & Canines & $\begin{array}{c}\text { Checkteeth } \\
\text { (permanent } \\
\text { teeth) }\end{array}$ \\
\hline \multicolumn{8}{|c|}{ Cultural breeds } \\
\hline $\begin{array}{l}\text { Data by Colyer } \\
(1906)^{*}\end{array}$ & 484 & - & - & - & - & - & 0.6 \\
\hline Data by Wafa $(1988)^{*}$ & 355 & - & - & - & - & - & 4.2 \\
\hline $\begin{array}{l}\text { Data by Peredelsky } \\
\text { (1927) }\end{array}$ & 245 & - & 0.8 & - & - & - & - \\
\hline $\begin{array}{l}\text { Data by Dixon et al. } \\
(1999 a, b)\end{array}$ & 400 & - & - & - & 0.7 & - & 5.7 \\
\hline $\begin{array}{l}\text { Data by Brigham \& } \\
\text { Duncanson (2000a) }\end{array}$ & 50 & - & 6 & - & 4 & 6 & - \\
\hline \multicolumn{8}{|c|}{ Aboriginal breeds } \\
\hline Kazakh & 61 & - & - & 1.6 & - & - & - \\
\hline Yakut & 68 & - & - & - & - & - & - \\
\hline Mongol & 21 & - & - & 4.8 & - & - & - \\
\hline Bashkir & 10 & - & - & - & - & - & - \\
\hline Yomud & 12 & - & - & - & - & - & - \\
\hline Island & 78 & - & - & - & - & - & - \\
\hline \multicolumn{8}{|c|}{ Feral horses } \\
\hline Vodny Island & 473 & 0.8 & - & 0.4 & 0.4 & - & 2.1 \\
\hline
\end{tabular}

* after Dixon et al. (1999b).

Table 3. Records of inherited dental anomalies (polydonty) in the domestic horses.

\begin{tabular}{|c|c|c|c|c|c|c|c|}
\hline \multirow[b]{3}{*}{ Breeds } & \multirow{3}{*}{$\begin{array}{l}\text { Total } \\
\text { number of } \\
\text { skulls }\end{array}$} & \multicolumn{6}{|c|}{ Types of inherited dental anomalies (in \% to total) } \\
\hline & & \multicolumn{3}{|c|}{ True polydonty } & \multicolumn{3}{|c|}{ False polydonty } \\
\hline & & Incisors & Canines & $\begin{array}{c}\text { Checkteeth } \\
\text { (permanent } \\
\text { teeth) }\end{array}$ & Incisors & $\underset{* * *}{\operatorname{Canines}}$ & $\begin{array}{l}\text { Checkteeth } \\
\text { (permanent } \\
\text { teeth) -P1 }\end{array}$ \\
\hline \multicolumn{8}{|c|}{ Cultural breeds } \\
\hline Data by Colyer (1906)* & 484 & - & - & 2.5 & - & - & - \\
\hline $\begin{array}{l}\text { Data by Peredelsky } \\
\text { (1927) }\end{array}$ & 350 & - & - & - & - & $\begin{array}{l}\text { from } 2- \\
3 \text { to } 5.7\end{array}$ & - \\
\hline Data by Rudick (1973) & 40 & - & - & - & - & - & 5 \\
\hline Data by Gromova (1949) & not indicated & - & - & - & - & - & 12 \\
\hline Data by Baker (1979)** & not indicated & - & - & - & - & - & 13 \\
\hline Data by Wafa $(1988)^{*}$ & 355 & - & - & - & - & - & 31.9 \\
\hline $\begin{array}{l}\text { Data by Dixon et al. } \\
(1999 \mathrm{a}, 1999 \mathrm{~b})\end{array}$ & 400 & 1 & - & 2.5 & 1.2 & - & - \\
\hline $\begin{array}{l}\text { Data by Brigham, } \\
\text { Duncanson (2000a) }\end{array}$ & 50 & - & 3 & - & - & - & 4 \\
\hline $\begin{array}{l}\text { Data by Brigham, } \\
\text { Duncanson }(2000 \mathrm{~b})\end{array}$ & 100 & - & - & - & - & - & 10 \\
\hline \multicolumn{8}{|c|}{ Aboriginal breeds } \\
\hline Kazakh & 61 & - & - & - & - & 28 & 16.4 \\
\hline Yakut & 68 & - & - & - & - & 29.2 & 22 \\
\hline Mongol & 21 & - & - & - & - & 80 & 14.3 \\
\hline Bashkir & 10 & - & - & - & - & - & 50 \\
\hline Yomud & 12 & - & - & - & - & 40 & 8.3 \\
\hline Island & 78 & - & - & - & - & 34.6 & 29.5 \\
\hline \multicolumn{8}{|c|}{ Feral horses } \\
\hline Vodny Island & 473 & - & - & - & - & 12.5 & 26.2 \\
\hline
\end{tabular}

* after Dixon et al. (1999b); ** after Brigham \& Duncanson (2000a); *** false polidonty of the canines calculated for the adult females only (see Tab. 1.). 
Table 4. Records of inherited dental anomalies (developmental anomalies) in the domestic horses.

\begin{tabular}{|c|c|c|c|c|}
\hline \multirow[b]{2}{*}{ Breeds } & \multirow{2}{*}{$\begin{array}{c}\text { Total number of } \\
\text { skulls }\end{array}$} & \multicolumn{3}{|c|}{ Types of inherited dental anomalies (in \% to total) } \\
\hline & & Incisors & Canines* & $\begin{array}{c}\text { Checkteeth } \\
\text { (permanent teeth) }\end{array}$ \\
\hline \multicolumn{5}{|c|}{ Aboriginal breeds } \\
\hline Kazakh & 61 & - & 13.8 & 1.6 \\
\hline Yakut & 68 & - & - & 1.4 \\
\hline Mongol & 21 & - & - & - \\
\hline Bashkir & 10 & - & - & - \\
\hline Yomud & 12 & - & - & - \\
\hline Island & 78 & - & 30.8 & - \\
\hline \multicolumn{5}{|c|}{ Feral horses } \\
\hline Vodny Island & 473 & 0.4 & 1.2 & - \\
\hline
\end{tabular}

* Canine hypoplasia calculated for the adult males only (see Tab. 1).

Table 5. Frequency of polidonty of P1 in the feral horses population of Vodny Island, Ciscaucasia (South Russia).

\begin{tabular}{|l|c|c|c|}
\hline Years of birth & Number of specimens & Number of specimens with anomalies & Frequency of anomalies (\%\%) \\
\hline $1991-1995$ & 23 & - & - \\
\hline $1996-2000$ & 49 & 4 & 8.2 \\
\hline $2001-2005$ & 181 & 36 & 19.9 \\
\hline $2006-2010$ & 220 & 84 & 38.2 \\
\hline
\end{tabular}

in the adult mares (28-80\%, 35.2\% in average) and of the 1 st praemolar in all horses $(8.3-50 \%, 23.4 \%$ in average) appeared to be more frequent as compared to the cultural breeds, judging by respective figures, $2-3$ to $5.7 \%(3,6 \%$ in average $)$ and $4-13 \%$ ( $8 \%$ in average) (Tab. 3). These differences between groups of the aboriginal and cultural breeds are statistically nearly significant $(\chi 2=2.94, \mathrm{p}=0.08)$.

Frequency of dental anomalies in the isolated horse populations

Dental anomalies can be used as an indication of inbreeding in mammal populations (Belyaev, 1972). Based on this supposition, we studied two isolated island populations of the domestic horse. The one of them is the Vodny Island population, which is known to exist in isolation for at least two last decades (Spasskaya et al., 2010). Much more older, however, is another isolated horse population, that of the Island horse breed, which has become isolated since 930 .

Analysis of the skulls of the Vodny Island feral horses indicated that all the above dental anomalies occur in this population (Tab. 2-4). Thus, olygodonty is recorded with frequency of $0,4-0,8 \%$ (canines $0 \%$ ), frequency of misalignment is $0.4-2.1 \%$ (canines $0 \%$ ), that of false polydonty in canines and in $\mathrm{P} 1$ reaches 12.5-26.2\% (incisors $0 \%$ ), and developmental anomalies are as frequent as $0.4-1.2 \%$ (checkteeth $0 \%$ ).

As to the Island horse population, not all of the above anomalies were recorded in it, while frequency of those actually revealed appeared to be several times higher than in the Vodny Island population (Tab. 2-4). In the Island horse, frequencies of false polydonty in canines and in P1 reach $34.6 \%$ and $29.5 \%$, respectively, and developmental anomalies are as frequent as $30.8 \%$. The difference between the two isolated horse population being compared is highly significant $(p<0,001)$, which agrees with the above concept of accumulation of anomalies with the long-time isolation.

In addition, we analyze temporal dynamics of frequencies of dental anomalies within the Vodny Island population; for this, P1 polydonty was used as the most common dental malformation (see above). It was revealed that portion of the horses with additional P1 increased significantly from those born in 1991 to those born in $2010(\chi 2=9.8, p=0.002$, Table 5), which is in agreement with the background supposition.

It is to be noticed, in brackets, that in the Przewalskii's horse population having been bred in captivity for more than 100 years and being characterized by high level of inbreeding, a similar correlation of increasing of $\mathrm{P} 1$ polydonty with degree of inbreeding coefficient was reliably demonstrated $(p<0.05)$ (Spasskaya, 2001).

\section{Conclusion}

Based on numerical analysis of data on dental anomalies in various breeds of the domestic horse obtained from both original and published data, it was shown for the first time that frequencies of these anomalies is higher in the aboriginal breeds than in the European 
cultural breeds.

It is to be stressed especially that these differences are, among other things, due to occurrence of atavistic features in the former lacking in the latter.

Differences between age groups by some dental anomalies appeared to be significant at least in some horse breeds. Some anomalies, in particular false polydonty of $\mathrm{P} 1$, is more often detected in younger animals, which is associated with possible loss of the tooth during the animal's life.

It is also shown that long-term isolation of the island horse populations leads to increase of the dental anomalies in them, most probably due to increase of inbreeding.

ACKNOWLEDGEMENTS. The author is deeply thankful to the curators of respective collections indicated above and to research associates, especially to $\mathrm{M}$. Sablin, I. Beloljubsky, G. Boeskorov, N. Lange, for their kind cooperation. I am indebted to I. Pavlinov for critical remarks; D. Morzhina for assistance in collecting and processing of the skull materials on the Vodny Island feral horse.

\section{References}

Belyaev D.K. 1972. [Genetic aspects of animal domestication] // Matveev B.S. (ed.). [Problems of domestication of animals and plants]. Moskva: Nauka. P.39-45 [in Russian].

Brigham E.J., Duncanson G.R. 2000à. An equine postmortem dental study: 50 cases // Equine Veterinary Education. Vol.12. No.2. P.59-62.

Brigham E.J., Duncanson G.R. 2000b. Case study of 100 horses presented to an equine dental technical in the UK // Equine Veterinary Education. Vol.12. No.2. P.63-67.

Dixon P.M., Dacre I. 2005. A review of equine dental disorders // The Veterinary Journal. Vol.169. P.165-187.

Dixon P.M., Tremaine W.H., Pickles K., Kuhns L., Hawe C., McCann J., McGorum B., Ralton D.I., Brammer S. 1999a. Equine dental disease Part 1: A long-term study of 400 cases: disorder of incisor, canine and first premolar teeth // Equine Veterinary Journal. Vol.31. No.5. P.369-377.

Dixon P.M., Tremaine W.H., Pickles K., Kuhns L., Hawe C., McCann J., McGorum B., Ralton D.I., Brammer S. 1999b. Equine dental disease Part 2: A long-term study of 400 cases: disorder of development and eruption and variations in position of the cheek teeth // Equine Veterinary Journal. Vol.31. No.6. P.519-528.

Durst W. 1936. [Exterior horse]. Moskva-Leningrad: Selkhozgiz. 344 p. [in Russian]

Easley J. 2006. Equine dental developmental abnormalities // Equine Dentistry Focus Meeting. Indianapolis: American Association of Equine Practitioners.
Gromova V.I. 1949. [History horses (genus Equus) in the Old World. Part 2. The evolution and classification of the genus] // Trudy Paleontologicheskogo Instituta AN SSSR. Vol.17. No.2. 162 p. [in Russian]

Korneven Sh., Lesbr F.-K. 1932. [Recognition of age in the teeth and derived epithelium]. Moskva-Leningrad: Gosizdatel'stvo sel'skohozjaistvennoi i kolhozno-kooperativnoi literaturu. 213 p. [in Russian]

Kuleshov P.K., Krasnikov A.S. 1928. [Determining the age of farm animals]. Moskva: Gosudarstvennoe izdatel'stvo. 120 p. [in Russian]

Penzhorn B.L. 1984. Dental abnormalities in free-rangong cape mountain zebra (Equus zebra zebra) // Journal of Wildlife Desaeses. Vol.20. No.2. P.161-166.

Peredelsky A.A. 1927. [Canine of the horse as a secondary sexual characteristic] // Trudy Laboratorii eksperimental'noy biologii Moskovskogo zoparka. Vol.3. P.201-236. [in Russian].

Peters J.W., de Boer B., Broeze-ten G.B.M., Broeze J., Wiemer P., Sterk T., Spoormakers T.J.P. 2006. Survey of common dental abnormalities in 483 horses in the Netherlands // Equine Dentistry Focus Meeting. Indianapolis: American Association of Equine Practitioners.

Rudick S.K. 1973. [Random dental anomalies in horses] // Vestnik Zoologii. Vol.1. P.82-83 [in Russian].

Bateson W. 1894. Materials for the study of variation treated with especial regard to discontinuity, in the origin species. London: Macmillan and Co and New York. 598 p.

Spasskaya N.N., Pavlinov I.Ya. 2008. [Variability and correlation structure of cheek teeth of Przewalski's horse (Equus przewalskii; Mammalia: Equidae)] // Bulleten Moskovskogo Obschestva Ispytatelei Prirody. Otdel Biologii. Vol.113. No.2. P.3-13 [in Russian, with English summary].

Spasskaya N.N., Yanishevskii B.E. 2013. [Horses of sanitary burial place 1812 at the village of Borodino: identification of breeds] // Zoologicheskii Zhurnal. Vol.92. No.9. P.1162-1178 [in Russian, with English summary].

Spasskaya N.N. 2001. [Intraspecific morphological variability of the Przewalski horse (Equus przewalskii Poljakov, 1881)]. PhD Thesis. Institut problem ekologii i evoljucii im. A.N. Severtsova RAN. Moscow. 323 p. [in Russian] Spasskaya N.N., Ermilina J.A., Makhotkina K.A., Svinarenko A.E. 2010. [Phenotypic characterization of an isolated population of feral horses Vodny Island (Rostov Reg.)] // Bulleten Moskovskogo Obschestva Ispytatelei Prirody. Otdel Biologii. Vol.110. No.6. P.15-23 [in Russian, with English summary].

Svechin K.B. 1976. [Individual development of farm animals]. Moscow: Urozhay. 284 p. [in Russian]

Vokken G.G., Glagolev P.A., Bogolyubsky S.N. 1961. [Anatomy of domestic animals: anatomy of movement]. Moscow: Kolos. 390 p. [in Russian]

Yasui K. 2009. Numeral anomalies of teeth observed in a reared Malayan tapir (Tapirus indicus) // Science Report of the Toyohashi Museum of Natural History. Vol.19. P.1-6. 


\section{Appendix 1}

The list of specimens used for analysis of dental anomalies. Information is in the following order: breeds names, museum in parenthesis, specimen ID (followed by field ID in parenthesis if needed), sample size in parenthesis.

Kazakh breed (Zoological Institute RAS, St. Petersburg, Russia) - 17978-99, 18000-38 (n = 61).

Yakut breed (Zoological Institute RAS, St. Petersburg, Russia) - 5233-35, 7169, 12614-20, 15241, 15245, 15699-01, 16156-57, 29697 (n = 19); (Zoological Museum of Lomonosov Moscow State University, Moscow, Russia) - 181390-98 ( $=10)$; (Geological Museum of Diamond and Precious Metal Geology Institute Siberian Branch of the Russian Academy of Sciences, Yakutsk, Russia) - 3-12, 16, 17, 33, 34, 1246, 1944, 1953, 4692, 4693, 1921-22, 1931-32, 1933-34, 1947-48, 1949-50, 1951-52, 1955-56, 1957-58, 1959-60, 1(13), 2(14), 3(15), 5833 ( $\mathrm{n}=32$ ); (State Museum of History and Culture of Northern Peoples, Yakutsk, Russia) — 5 skulls without ID $(\mathrm{n}=5)$; (Arheological Museum Yakutsk State University, Yakutsk, Russia) - 2 skulls without ID $(\mathrm{n}=2)$.

Mongol breed (Zoological Institute RAS, St. Petersburg, Russia) - 5230-31, 7202, 18055-59, 20135-37 ( $\mathrm{n}=$ 11); (Zoological Museum of Lomonosov Moscow State University, Moscow, Russia) - 110476, 110478, 134563 , 163569 ( $n=4)$; (Agriculture University of Mongolia, Ulan-Bator, Mongolia) - 6 skulls without ID $(n=6)$.

Yomud breed (Zoological Institute RAS, St. Petersburg, Russia) - 18039-50 ( $\mathrm{n}=12)$.

Bashkir breed (Zoological Museum of Lomonosov Moscow State University, Moscow, Russia) - 18462733, 184743, 187006, $190398(\mathrm{n}=10)$.

Island breed (Museum of Natural History of Humboldt University, Berlin, Germany) - 1322-1400 ( $\mathrm{n}=78)$. 